\title{
CrimRxiv
}

\section{Alcohol outlets, social disorganization, and non- violent crimes in urban neighborhoods}

Aleksandra J. Snowden, Thomas D. Stucky, William Alex Pridemore

Published on: Jul 05, 2021

License: Creative Commons Attribution 4.0 International License (CC-BY 4.0). 
